University of Nebraska - Lincoln DigitalCommons@University of Nebraska - Lincoln

To Improve the Academy

Professional and Organizational Development

Network in Higher Education

1993

\title{
New Trends in Assuring and Assessing the Quality of Educational Provision in British Universities
}

George Gordon

Follow this and additional works at: http://digitalcommons.unl.edu/podimproveacad

Part of the Higher Education Administration Commons

Gordon, George, "New Trends in Assuring and Assessing the Quality of Educational Provision in British Universities" (1993). To Improve the Academy. 280.

http://digitalcommons.unl.edu/podimproveacad/280

This Article is brought to you for free and open access by the Professional and Organizational Development Network in Higher Education at DigitalCommons@University of Nebraska - Lincoln. It has been accepted for inclusion in To Improve the Academy by an authorized administrator of DigitalCommons@University of Nebraska - Lincoln. 


\section{New Trends in Assuring and Assessing the Quality of Educational Provision in British Universities}

\section{George Gordon}

Strathclyde University

Glasgow, Scotland

This article describes recent initiatives designed to audit and assess the quality of education in British universities. Such concerns are not new and have been addressed in various ways, including the accreditation of programs by professional bodies and of programs and institutions by regional accreditation/validation bodies. In essence these initiatives, old and new, seek to provide assurance, to the academy and to the public, that standards are appropriate, satisfactory, compatible with objectives, and broadly comparable between similar programs or institutions. At present, there is a gathering international movement toward requiring universities to produce evidence about their systems of quality assurance and control. Paradoxically, while these requirements place additional demands upon the academy, they offer new opportunities for faculty developers.

\section{Context}

As Booth and Roper (1992) have stated, the proposed policies contained in the British government White Paper on higher education, Higher Education: A New Framework (DES 1991), expressed concern about assessing and enhancing the quality of research and teaching in 
British universities. External peer assessment of research has influenced the funding of research in British universities since the mid 1980s. The results of the latest exercise (1992) are now being evaluated by institutions and will have profound effects on academic decisions. However, this paper is concerned with the quality of educational provision as it relates to the experience of students.

The 1991 White Paper proposed that British polytechnics could seek the right to the title and status of universities. This has now occurred, and the former polytechnics are now described as the new universities. There are now over $\mathbf{9 0}$ old and new universities in the British system of higher education.

A further proposal, to establish separate funding councils for higher education in England, Scotland, and Wales, has also been enacted. Those bodies are now operating and have assumed full responsibilities for funding of higher education.

The final contextual point has had a profound effect. In the early 1980 s, the old universities came under pressures from various sources. They arose from concerns for efficiency, economy, and greater accountability for the use of public funding. Questions were asked about the relevance of courses to the needs of employers and society. Questions arose about standards associated with what some perceived by to be an expensive, yet inefficient, educational process.

Legally, British universities had autonomous powers in academic matters, while the programs of polytechnics were subject to scrutiny by the Council for National Academic Awards (CNAA). Actually, the situation was more complex. For example, university programs leading to professional qualifications are accredited by the appropriate professional bodies. Moreover, the use of external examiners is commonplace in British universities. In 1990 these pressures for change led the Committee of Vice Chancellors and Principals (CVCP) to establish an Academic Audit Unit to:

(a) review the universities' mechanisms for monitoring and promoting the academic standards necessary for achieving their stated aims and objectives,

(b) comment on the extent to which procedures in place in individual universities both reflect best practice in maintaining quality and are applied in practice, 
(c) identify and commend to universities good practice in maintaining academic standards at the national level, and

(d) keep under national review the role of the external examiner system.

\section{Implications for Faculty Developers}

The fact that the academic audit asks about the arrangements for faculty development has provided a substantial boost to existing arrangements, programs, and budgets. Audit reports always mention these issues and suggest areas for enhancement and/or review. The overall effect is to move faculty development center stage. Similarly, the demands of audit and assessment can encourage faculty to see faculty development as a helpful and purposeful activity that supports them in a time of need (even stress).

Thereafter the range of action and response is substantial, depending upon a variety of factors including the prevailing views and traditions in the institution and the views and preferences of the faculty developers.

All new procedures and policies have the potential for changing relationships, structures, power balances, and networks. Quality audit and quality assessment appear to conform to that potential. Faculty developers can elect to promote the new policies and procedures, support faculty grappling with them, and/or criticize weaknesses of methodology or philosophy. It is certainly possible to pursue two of the options simultaneously. Indeed, faculty developers can, if they choose, exercise all of them at the same time. For example, it is possible to help colleagues understand a procedure and develop ways of operationalizing it, while seeking to amend the external methodology/philosophy by argument and publication.

Only a minority of faculty developers are likely to have the range of experience that would make it sensible for them to contribute to all aspects of quality audit or quality assessment. However, the overwhelming majority of developers and development centers have considerable expertise in many of the eleven aspects covered by quality assessment in Britain (e.g., curriculum design and review, learning 
resources, course organization, teaching and learning practice, assessment and monitoring).

Many developers may have qualms about becoming involved with external, imposed practices that faculty dislike or mistrust, fearing criticism or even hostility, opposition, and rejection. There are dangers and they should not be forgotten, but there are also genuine opportunities to work with more willing colleagues and volunteers than might come your way under different conditions. Perhaps the most important thing for faculty developers to consider is that audit and quality assessment encourage, perhaps enforce, reflection on the quality of teaching and learning. They move these topics closer to center stage, something close to the hearts of many faculty developers.

The author is familiar with many examples of excellent work by faculty developers in North America through POD and To Improve the Academy, in Canada through the Society for Teaching and Learning in Higher Education, in Australia through the Higher Education Research and Development Society of Australasia (notably their Green Guides and leaflets) and, more recently, in Britain through the work of the Universities Staff Development Unit, the Staff Development Group of the Society for Research in Higher Education, the Standing Conference on Educational Development and the regional groups that have been formed (notably in Scotland, in Northern England, the East Midlands and the South West). Typically these groups work with others and develop, promote, and publicize good practice. They flourish best when the vital ingredients of enthusiasm, experience, credibility, and trust are nurtured in a supportive environment by senior faculty and senior administrators. Requiring participation and involvement may tend to be alien to our values and philosophy, yet when they become part of accepted practice or the normal "climate" of an institution, they should not impede growth and development. A crucial strategic question for British faculty developers may be: will quality audit and quality assessment become "accepted practice" in the short to medium term in institutions of higher education?

Certainly these developments present faculty developers with interesting challenges. They also may lead to a more coherent and integrated approach to the complex, multi-stranded and important 
topic of faculty development, which ranges from the development of teaching assistants to heads of departments and senior administrators. It also includes teaching methods, curriculum design, and methods of assessment, Increasingly, it involves institutional mission; objectives for departments and individuals performances and the means of monitoring, evaluating, and enhancing these faculty-based indicators and matching them with the needs and views of students; the promotion of effective learning; and the enrichment of the learning experiences of students.

\section{Academic Audit}

Academic Audit in Great Britain relates to programs of study, not research, although all postgraduate education falls within its scope.

A small core of full-time Audit staff (Director, Deputy Director and Administrator) was recruited. A team of academics released from their institutions for twenty percent of their time for two years serve as the academic auditors. The founding group, of which the author was a member, was "trained" prior to conducting five pilot audits in the Spring of 1991. The full program commenced with the objective that all institutions, the old universities as they are now described, would be audited by 1993 .

Academic Audit follows the practice of fitness for purpose. That is, it examines the policies, mechanisms, and procedures for quality assurance in an institution in relation to the aims and objectives of the institutions, rather than testing them against a gold standard. Particular attention is paid to: (a) the provision and design of new programs of study, (b) the monitoring and evaluation of existing programs, (c) quality assurance in teaching/learning, (d) development and review within the academy, and (e) evaluative feedback (from students, employers, external examiners, etc.).

Audit is based upon a visitation to the institution, normally by three auditors for a period of three days. During the visit the team meets with various committees, groups, and individuals, including students. The purpose of these discussions is to examine the quality assurance procedures and mechanisms and see if they are applied in practice, if there are any gaps in policy, and if the policies appear to 
display good practice. In many ways the process broadly resembles that of regional accreditation bodies in the United States. In total, the auditors commonly meet with between 100 and 150 academics and students during an audit visit.

After the visit, a report (around 16 to 20 pages) is prepared. The report covers each section of the remit of audit and concludes with a list of commendations and of suggested matters for the institution to reconsider.

\section{Recurrent Issues}

At the start of 1993, the majority of the old universities have been audited. While the detailed points emerging from audit differ from institution to institution and over time, some issues tend to recur. One of the most pervasive is how an institution knows that its system of quality assurance works and that it is a good one. Audit tends to cause institutions to reflect upon the degree of internal diversity of practice and policy that is acceptable in a sound system of quality assurance. Audit is not seeking uniformity but it does expect institutions to evaluate policies and practices and to be capable of knowing and showing that they work. "We do it differently here" is not axiomatically correct or incorrect; it is often merely historic practice.

Similar to the Assessment Movement in the United States, virtually every institution is grappling with the task of designing ways to incisively monitor existing programs, scrutinize new programs, and avoid voluminous checklists and paper mountains. Audit raises many questions about the nature and quality of the student experience, about systems of feedback and supervision, about faculty development, about the reward and recognition of excellent teaching, about evaluating and monitoring policy and practice, and about the implementation of recommendations for enhancement. In essence, institutions and individual members of faculty are confronted with the need to make quality assurance explicit. It must be shared and capable of being examined by people from outside the institution, rather than the position being implicitly assumed. 


\section{Potential Threat}

Does audit pose a threat to the academy? Martin Trow (1992) has argued in commenting on the White Paper on Higher Education in Britain: "It is evident that trust between institutions of higher education and central government in the UK is low" (p. 222). Often auditors are confronted by the response that fellow academics trust their colleagues as experts and therefore there is no need to get external views on academic proposals or standards. This is a very real, important, and sensitive issue, yet most people would accept that while quality assurance requires commitment, integrity, and honesty, it cannot simply consist of trusting one's colleagues to do a good job. The challenge to everyone involved in higher education in Britain (and in other countries which have introduced, or are about to introduce, academic audit) is to ensure that the process is meaningful and helpful, that the intrusion is minimal, effective, and efficient, and that the primary responsibility rests with institutions and the academy. It is my contention that much depends upon the academy accepting the challenge and attaching importance to it. That requires leadership but also support. Faculty developers play a key role in providing expert support.

\section{Quality Audit}

Recently Academic Audit has been transformed into the Division of Quality Audit. It is no longer accountable to the CVCP but to a new body, the Higher Education Quality Council. This Council is accountable to all institutions of higher education in Britain. In addition to changes in organizational responsibility, there will be some amendments to the process of the academic audit. For example, promotional material of institutions (prospectuses, promotional videos, etc.) will be scrutinized.

\section{Quality Assessment}

The Higher Education White Paper (1991) proposed that the new funding councils should be informed about the quality of programs in institutions of higher education. In autumn 1991, a Working Party was 
established consisting of representatives from the polytechnics and universities. They were charged with developing a methodology for quality assessment. The methodology was piloted in four institutions in England and four in Scotland early in 1992. In England the pilots involved engineering and physical sciences and in Scotland they covered engineering and business studies. Most of the assessors were academics drawn from institutions of higher education, but key, core assessors were members of Her Majesty's Inspectorate (Higher Education Division). Historically, the members of the Inspectorate have had powers to inspect primary and secondary schools, colleges of further education and teacher training colleges, polytechnics and, by invitation, university departments involved in the training of schoolteachers. Additionally, each team had an independent chair who reported on the process to the Working Party.

Each visit lasted five days. There was extensive advance consultation about details of the visit, considerable discussion during the visit, preliminary debriefing of the institution before the teams left, and consultation over the actual reports before they were finalized.

Serious and substantive questions were raised about the reliability of the process, its intrusiveness, and the cost of the exercise, including the opportunity cost of releasing academics to act as assessors and the larger costs of areas preparing for assessment.

In Scotland, a Joint Working Group, established by the Committee of Principals of the Scottish Universities and Colleges, argued for a simpler system which made greater use of material supplied by institutions.

In September 1992, the Scottish Higher Education Funding Council (SHEFC) issued a Consultative Paper on Assessment of Quality. It indicated that the Council proposed to conduct assessments of economics and electronic and electrical engineering (in England and Wales it was further pilots involving Law and Business Studies) in 1992-1993, using a three point scale for overall quality assessment and drawing upon the results of institutions' own quality assessment of these subjects.

In October the SHEFC issued a statement of the arrangements for quality assessment for 1992-1993. A three point scale was used for assessments in 1992-1993: excellent (provision is satisfactory in all 
aspects and outstanding in most), satisfactory (provision is satisfactory in most aspects and, overall, strengths outweigh weaknesses), and unsatisfactory (provision is unsatisfactory in several aspects and, overall, weaknesses outweigh strengths).

The eleven key aspects in the framework were:

Aims and Curricula

Curriculum Design and Review

The Teaching and Learning Environment

Staff Resources

Learning Resources

Course Organization

Teaching and Learning Practice

Student Support

Assessment and Monitoring

Students' Work

Output, Outcomes and Quality Control.

Several elements articulate, describe, and define each aspect.

Along with the self-assessment documentation, institutions were expected to submit course documentation, external examiners' reports for the past two years, recent internal monitoring/evaluation reports (where available), and lists of courses constituting provision in the particular cognate area with details of enrollments for the past two years.

The procedure adopted for 1992-1993 entailed self-assessment arguing a case for a particular grading, i.e., excellent, satisfactory, unsatisfactory. It was possible that the evaluators, after inspecting the documentation, could confirm a satisfactory self-grading. However visits occurred in every case, regardless of the self-assessment claim.

Prior to these visits, institutions supplied statements of institutional mission and departmental aims; comprehensive lists of faculty; information on the organization of the department, specialist accommodation, and facilities; and student services, both at the institutional and departmental level; data for the past two years on the student intake (entry scores), progression rates, graduation statistics, and first destinations of graduates; and performance indicators and current qualityrelated policy statements. During the visit, the assessors received layout plans of facilities, details of support staff, student feedback data, 
details of assessment arrangements, samples of marked student work and student timetables, and faculty availability for the period of the visit.

Most of the assessors were recruited from within the Scottish system, but about one-quarter were drawn from England and Ireland. The assessment teams included one core member and one person drawn from industry, in addition to academics from the relevant discipline. Institutions will receive short reports which will be published in June 1993.

A comprehensive program of assessments embracing most academic disciplines is being introduced in the next five years. Assessments in a cognate area will be conducted within the same academic year.

It is likely that faculty, educational and organizational development will be recurrent themes in these reports on quality assessment - offering a further challenge to, and opportunity for, faculty developers. We live in exciting times.

\section{References}

Academic Audit Unit. (1992). Annual Report of the Director 1990/91. Birmingham, England: Committee of Vice-Chancellors and Principals (CVCP).

Booth, C.,\& Roper, B. (1992). A new framework for quality. Higher Education Quarterly, $46(3), 227-242$.

Committee of Vice-Chancellors and Principals.(1990, May). [Establishment of the academic audit unit]. Letter from the CVCP.

Committee of Vice-Chancellors and Principals. (1991) Notes for the guidance of auditors. Birmingham, England: CVCP.

DES. (1991). Higher education: A new framework. Cmd 1541 London: DES.

Gordon, G. (1993). The audit and assessment of teaching quality: An auditors' view. The Audit Assessment of Teaching Quality. Birmingham, England: Standing Conference on Educational Development, 101-112.

The Scottish Higher Education Funding Council. (1992, June). [Quality assessment arrangements for 1992-1993]. Circular letter.

Research rankings. (1992, December 18). The Times Higher Educational Supplement.

The Times Higher Educational Supplement. (1993, January 15).

Trow, M. (1992). Thoughts on the white paper of 1991. Higher Education Quarterly, 46(3). 213-226. 